\title{
Editorial
}

\section{El acceso universal a las vacunas: eliminar el canibalismo inmunológico}

Las vacunas han sido, hasta ahora, el alcance más importante de la medicina y el aporte, junto con el agua potable y el alcantarillado, que más vidas ha salvado, sin ninguna duda, en el planeta en la historia humana. Desarrollada solo hace dos siglos por Edward Jenner, las enfermedades infecciosas no han tenido peor enemigo que la inmunización, otrora bandera de la salud y la salud pública [1].

La inmunización, como muchos actos de la medicina, pasaron del terreno de lo sanitario, preventivo y público al tenebroso y oscuro registro del negocio. Lo que fuese un esfuerzo universal, humanitario y solidario se convirtió en un quehacer mercantil, protegido con el secreto comercial, lleno de insospechados tratos a escondidas, pactos misteriosos y, por supuesto, pagos de millones de dólares. Pasamos de la transparencia y la solidaridad, valores propios de la sanidad pública moderna, a los pactos ocultos y amenazantes, conducta común entre las mafias y en procederes de lo no debido.

Pensemos primero en el acto mismo de la inmunización. Inmunizar un solo ser humano, desde el punto de vista de la salud pública, no es un logro relevante. La inmunización debe ser un acto colectivo, con el cual, como género humano, nos defendemos en conjunto de otro elemento conviviente en este ecosistema biológico en el que existimos y al que le ganamos un espacio durante millones de años de selectividad natural y adaptaciones biológicas [2]. Ese espacio se lo hemos ganado a otros, que incluso lo ocupaban antes que nosotros. Inmunizarse como individuo no es en logro adaptativo, es un acto de fe. La verdadera meta de la inmunización es el acto colectivo, es el triunfo como especie de lograr vencer, mediante las defensas, la enfermedad, que no es otra cosa que la consecuencia de otro conviviente del ecosistema que, como nosotros, lucha por ganarse un espacio.

Por eso, la verdadera inmunización debe ser colectiva, masiva, pública y, por supuesto, gratuita. No existe otra forma de vencer la pandemia que una inmunización masiva, que garantice el desarrollo de defensas en un porcentaje mayoritario de la población y, por ende, elimine la posibilidad de que el visitante se siga alojando en nuestro interior y se perpetúe su paso al hospedarse en otros seres humanos que le garanticen su supervivencia, a costa de la nuestra.

Para esto se necesita un compromiso humano, como especie, ante la amenaza masiva que implica una pandemia y el hecho innegable de que solo si nos defendemos en grupo, como lo hemos hecho como especie hasta ahora, vamos a sobrevivir en conjunto. De no hacerlo, vamos a caer en la falacia absurda que nos están vendiendo los mercaderes de la salvación, que promulgan, a su mejor estilo, que si como individuo compro la vacuna como si fuese un pasaporte a la sanación, sin importarme lo que le pase a ese otro humano, ajeno y distante, me libero de la condena a muerte en solitario, lo que me genera una ventaja frente el otro que no lo va a lograr y, por tanto, gano este espacio en la lucha de la existencia.

Nada más falso y menos cercano a la evidencia científica. Pero vende, y mucho, haciendo creer al consumidor que si se vacuna, el virus no va a entrar a su cuerpo y se salva. La vacuna lo que hace en realidad es impedir que el visitante se reproduzca en su interior, y solo repitiendo ese mecanismo en muchos, no en pocos, se vence la enfermedad.

Miremos con detenimiento la evidencia histórica: la viruela fue eliminada de la faz de la tierra gracias justamente a un esfuerzo sanitario público y universal cuando, bajo la tutela de la Organización Mundial de la Salud, a partir de 1958, prevalecieron los intereses comunes sobre los comerciales y la solidaridad entre los pueblos, entendiendo que vencer una enfermedad era una tarea de todos [3]. Eran otras épocas. La salud se regía prioritariamente por un principio fundamental de humanismo y ética, y el llamado a una acción colectiva fue escuchado solidariamente por quienes en ese entonces tomaban las decisiones sanitarias. Vencer una enfermedad es un logro de especie, no de individuo, no de gobierno, no de empresa.

En esa época, el éxito de un sistema de salud no se medía con indicadores de productividad, de eficacia económica o de número de ganancias. La salud no se vendía en tabletas, sino en actos. El verdadero indicador era estar sano, libre 
de la amenaza del agente infeccioso hospedado en mi congénere y, por lo tanto, se aplicaba el principio de ir a apagar el incendio del vecino para evitar que nos quememos todos. Y funcionó.

Hoy, lamentablemente, no es así. Los intereses económicos pronto encontraron que prometer sanidad, bienestar, sonrisas, tiempo de vida y salud era más rentable si se captura la voluntad del individuo que del grupo. Eliminar una enfermedad no es un negocio para quien vende la cura, por básico principio. Necesitamos el individuo enfermo, no sano, para venderle la salvación, en cómodas cuotas. Y de eso saben mucho los que venden los alivios, mas no las curas de las enfermedades.

La salud no debería estar expuesta al libre mercado, a las leyes de la oferta y la demanda, o al mejor postor. Partamos del principio universal de que la salud es un derecho, no es solo un servicio o un bien de consumo. Pero eso es otra discusión. Por supuesto, de alguna parte deberá salir el dinero suficiente para proveer salud, y en el caso del desarrollo de las vacunas, se necesita dinero para investigar y desarrollar el producto que en tiempo récord la ciencia logró sintetizar en diferentes versiones.

Pero tampoco es cierto que esta inversión sea exclusiva de la industria farmacéutica privada y que, por lo mismo, ellos deban reservarse su derecho al retorno de su inversión. Una gran parte de los fondos para el desarrollo tecnológico y de los presupuestos para los ensayos clínicos de las actuales vacunas no fueron inversión privada de las empresas farmacéuticas. Fueron, en un porcentaje, fondos públicos bajo la figura de donaciones, colaboraciones o proyectos asignados a universidades y centros de investigación, que destinaron ese dinero proveniente de los contribuyentes de varios países para lograr el desarrollo de las vacunas, su evaluación y validación [4].

Entonces: si esta situación es una emergencia sanitaria global, que implica decisiones en salud pública, que debe ser un esfuerzo global del género humano y, además, se financió por lo menos en una proporción, con fondos públicos, ¿cómo es posible que el mundo entero tenga que arrodillarse por turnos ante los mercaderes de la salvación, firmar acuerdos secretos con ellos, prometer lo divino y lo humano, para acceder a un pedazo de la torta sagrada de la sanación?

Solo hay una explicación: el sistema económico, y no el sistema sanitario, rige los destinos de la salud de los seres humanos. La extinción de la viruela fue un logro magnánimo de la salud publica global. Los ganadores fuimos todos los seres humanos. El fracaso frente al COVID-19 es la evidencia de que al entregar la salud del terreno de lo público al libre mercado y a intereses particulares habrá unos ganadores, sin duda, pero no seremos todos.

Dr. German Casas

Profesor Clínico Facultad de Medicina Universidad de Los Andes

Presidente para América Latina

Médicos Sin Fronteras

german.casas@msf.org

DoI: https://doi.org/10.17533/udea.rfnsp.e346159

\section{Referencias}

1 Riedel S. Edward Jenner and the history of smallpox and vaccination. Proc (Bayl Univ Med Cent). 2005;18(1):21-25. DOI: https://doi.org/10.1 080/08998280.2005.11928028

2 World Healt Organization. How the vaccines works? In: Vaccines and immunization: What is vaccination? [internet] 2020 dic. 30 [consulta $2021 \mathrm{abr}$. 12]. Disponible en: https://www.who.int/news-room/q-a-detail/vaccines-and-immunization-what-is-vaccination?adgroupsurvey $=\{$ ad groupsurvey $\}$ \&gclid=CjwKCAjwu5CDBhB9EiwA0w6sLdTxvpJaaYTQ8Nv8Was7rfsLaR3neNLe54bkhB6GJc6IBA8XNNGjzxoCuWoQAvD_BwE

3 Strassburg MA. The global erradication of smalpox. Am J Infect Control. 1982;10(2):53-9. DOI: https://doi.org/10.1080/08998280.2005.11928028

4 Medecins sans frontieres. Governmets must act fast on consensus supporting historic move to uspend monopolies during pandemic [interne]. 2020 dic. 15 [consulta 2021 abr. 12]. Disponible en: https://www.msf.org/covid-19-governments-must-build-consensus-around-waiver 